\title{
GENERAL MODEL OF WOOD IN TYPICAL COUPLED TASKS PART I. - PHENOMENOLOGICAL APPROACH
}

\author{
P. Koňas
}

Received: March 14, 2008

\begin{abstract}
KOŇAS, P.: General model of wood in typical coupled tasks. Part I. - Phenomenological approach. Acta univ. agric. et silvic. Mendel. Brun., 2008, LVI, No. 4, pp. 95-102

The main aim of this work is focused on FE modeling of wood structure. This task is conditioned mainly by different organized structures/regions (tissues, anomalies...) and leads to homogenization process of multiphysics declaration of common scientific and engineering problems. The crucial role in this paper is played by derivation of coefficient form of general PDE which is solvable by nowadays numerical solvers. Generality of supposed model is given by wide range of coupled physical fields included in the model. Used approach summarizes and brings together models for various fields of matter and energy common in wood material in wood drying process, but is also suitable for a lot of different tasks of similar materials. Namely microwave drying of wood with orthotropic, viscoelastic material properties together with time, moisture and temperature dependency of structural strains by modified mechanical properties were included. Specific matrixes of elasticity for individual fields were derived. Thermal field in wood was described by conduction type of spreading. Coupling of physical fields is based on diffusive character of temperature, moisture, static pressure fields movement.
\end{abstract}

FEM, multiphysics, wood drying

\section{THEORY}

Finite element modeling of such specific material as wood includes a lot of challenges in scope of mathematical and physical formulation, evaluation of experimental characteristics, specification of boundary conditions etc. Author tried to reveal some important moments, which should be crucial for general tasks in this branch of numerical analysis.

Let us assume that we want to solve some coupled problem typical for Wood Science and let us try to identify some major challenges. Modeling of wood drying process is one of the most complicated problems thus it should include large amount of more or less common tasks.

In our problem the microwave kiln supply the source of energy. The energy with dissipative character can be related to heated problem by density of energy $q_{a b s}$.

$\mathrm{q}_{\mathrm{abs}}=\omega \cdot \varepsilon_{\mathrm{eff}}^{\prime \prime} \cdot|\mathbf{E}|^{2}$ $\omega$ is angular velocity $\left(\mathrm{s}^{-1}\right), \varepsilon_{\text {eff }}^{\prime \prime}$ is effective relative loss factor, $\mathbf{E}$ is electric field $\left(\mathrm{V} . \mathrm{m}^{-1}\right)$.

Estimation of electric field together with magnetic field can be done by solution of reduced Maxwell's equations

$$
\begin{aligned}
& \nabla \times \mathbf{E}=\frac{\partial \mathbf{B}}{\partial t} \\
& \nabla \times \mathbf{H}=\mathbf{J}+\frac{\partial \mathbf{D}}{\partial \mathbf{t}} \\
& \nabla \cdot \mathbf{D}=\rho_{e} \\
& \nabla \cdot \mathbf{B}=0
\end{aligned}
$$

B is the magnetic flux density, $\mathbf{D}$ is electric flux density, $\mathbf{H}$ is magnetic field intensity, $\mathbf{J}$ is current density, $\rho_{e}$ is electric charge density. Due to anisotropy of wood we can itemize these variables to, where $\varepsilon$ is permittivity, $\mu$ is permeability and $\sigma$ is electric conductivity of material. 
Natural requirement for continual charge is satisfied by equation of continuity

$\nabla \cdot \mathrm{J}=-\frac{\partial \rho_{e}}{\partial t}$.

Although the microwave type of drying has volumetric character, the heating is not uniform in the whole region. This fact is caused not only by aniso- tropic material properties, but also by specific geometry on lower scales. The phase change of water to steam can locally and dramatically change dissipation of microwave energy. These changes can occur as hotspot(s) in small regions of material (KRIEGSMANN, 1997). Temperature difference is compensated by thermal energy exchange between hotspot and narrow surroundings. Exchange is mainly conductive and can be rewritten in the following form.

$\rho C \frac{\partial \mathrm{T}}{\partial \mathrm{t}}-\left[\frac{\partial}{\partial \mathrm{x}}\left(\mathrm{k}_{11} \frac{\partial \mathrm{T}}{\partial \mathrm{x}}+\mathrm{k}_{12} \frac{\partial \mathrm{T}}{\partial \mathrm{y}}+\mathrm{k}_{13} \frac{\partial \mathrm{T}}{\partial \mathrm{z}}\right)+\frac{\partial}{\partial \mathrm{y}}\left(\mathrm{k}_{21} \frac{\partial \mathrm{T}}{\partial \mathrm{x}}+\mathrm{k}_{22} \frac{\partial \mathrm{T}}{\partial \mathrm{y}}+\mathrm{k}_{23} \frac{\partial \mathrm{T}}{\partial \mathrm{z}}\right)+\frac{\partial}{\partial \mathrm{z}}\left(\mathrm{k}_{31} \frac{\partial \mathrm{T}}{\partial \mathrm{x}}+\mathrm{k}_{32} \frac{\partial \mathrm{T}}{\partial \mathrm{y}}+\mathrm{k}_{33} \frac{\partial \mathrm{T}}{\partial \mathrm{z}}\right)\right]=\mathrm{q}_{\mathrm{abs}}$,

$\rho$ is density of material $\left(\mathrm{kg} \cdot \mathrm{m}^{-3}\right), \mathrm{C}$ is heat capacity $\left(\mathrm{J} . \mathrm{K}^{-1}\right), k_{i j}$ are heat conduction coefficients (kg.m.s. $\left.\mathrm{s}^{-3} \cdot \mathrm{K}^{-1}\right)$, T is temperature, $t$ is time.

In shortened notation we can write:

$\rho \mathrm{C} \frac{\partial \mathrm{T}}{\partial \mathrm{t}}-\nabla \mathbf{k} \nabla \mathrm{T}=\mathrm{q}_{\mathrm{abs}}$

$\mathbf{k}$ is matrix of heat conduction.

Also let us assume available demand on regulation of temperature gradient by convective type of thermal energy source e.g. in the following sense.

$\rho \mathrm{C} \frac{\partial \mathrm{T}}{\partial \mathrm{t}}-\nabla \mathbf{k} \nabla \mathrm{T}=\mathrm{q}_{\mathrm{abs}}+\mathrm{k}_{\mathrm{h}_{\mathrm{T}}} \cdot\left(\mathrm{T}_{\mathrm{ext}}-\mathrm{T}\right)$,

$k_{h_{T}}$ is heat transfer coefficient $\left.\left(\mathrm{Wm}^{-2} \mathrm{~K}^{-1}\right)\right), T_{e x t}$ is temperature in the near surroundings $(\mathrm{K})$.

However thermal and electro-dynamical effects are not alone. There is among other things influence of moisture and pressure change in porous material such as wood. Content of water in the material is obviously separated into free water and water bonded through the H-bridges (the chemical bonded water by stronger types of bindings we will omit now). Bonded water keeps diffusive law of transport and notation is very similar to previous relationships of heat transport. Widely disputed is diffusive character of static pressure, from this reason the last equation is often omitted in the following system.

$\rho \mathrm{C} \frac{\partial \mathrm{T}}{\partial \mathrm{t}}-\nabla \mathbf{k}_{\mathrm{Tw}} \nabla \mathrm{w}-\nabla \mathbf{k}_{\mathrm{Tp}} \nabla \mathrm{p}-\nabla \mathbf{k}_{\mathrm{TT}} \nabla \mathrm{T}=\mathrm{q}_{\mathrm{abs}}+\mathbf{k}_{\mathrm{h}_{\mathbf{T}}}\left(\mathrm{T}_{\text {ext }}-\mathrm{T}\right)$

$\frac{\partial \mathrm{w}}{\partial \mathrm{t}}-\nabla \mathbf{k}_{\mathrm{ww}} \nabla \mathrm{w}-\nabla \mathbf{k}_{\mathrm{wp}} \nabla \mathrm{p}-\nabla \mathrm{k}_{\mathrm{wT}} \nabla \mathrm{T}=\mathbf{k}_{\mathrm{h}_{\mathrm{w}}}\left(\mathrm{w}_{\mathrm{ext}}-\mathrm{w}\right)$

$\frac{\partial \mathrm{T}}{\partial \mathrm{t}}-\nabla \mathbf{k}_{\mathrm{pw}} \nabla \mathrm{w}-\nabla \mathbf{k}_{\mathrm{pp}} \nabla \mathrm{p}-\nabla \mathbf{k}_{\mathbf{p} \mathbf{T}} \nabla \mathrm{T}=\mathbf{k}_{\mathbf{h}_{\mathbf{T}}} \cdot\left(\mathrm{p}_{\mathrm{ext}}-\mathrm{p}\right)$,

$w$ is mass concentration (moisture content), $w_{\text {ext }}$ respective $p_{e x t}$ is moisture content respective static pressure in the surroundings, $\mathbf{k}_{\mathrm{hw}}$ respective $\mathbf{k}_{\mathrm{hp}}$ are coefficients of convective type of fluxes, $\mathbf{k}_{\mathrm{Tw}}, \mathbf{k}_{\mathrm{Tp}}, \mathbf{k}_{\mathrm{TT}}$, $\mathbf{k}_{\mathrm{ww}}, \mathbf{k}_{\mathrm{wp}}, \mathbf{k}_{\mathrm{wT}}, \mathbf{k}_{\mathrm{pw}}, \mathbf{k}_{\mathrm{pp}}, \mathbf{k}_{\mathrm{pT}}$ are matrixes of diffusion coefficients.

These equations don't describe behavior of this region in environment with mechanical forces. Some of more general material model used for task of stressstrain relation usable for wood is viscous-elastic model. The typical model can be revised according to memory effect, which reveals mainly in cyclic loading of wood. Mechanical energy dissipation and its transformation into heat were not considered. It is proposed, that actual state of stress/strain depends on previous way of loading.

$\frac{\partial \sigma}{\partial \tau}=\frac{\partial}{\partial \tau} \mathbf{D} \varepsilon_{\mathbf{c}}{ }^{\mathbf{e l}}+\Phi(t-\tau) \frac{\partial \varepsilon_{\mathbf{c}}{ }^{\mathbf{v e l}}}{\partial t}$,

$\varepsilon^{\mathrm{el}}$ is immediate elastic strain (structural), $\varepsilon^{\mathrm{vel}}{ }_{\mathbf{c}}$ is viscous-elastic part of strain (structural), $\Phi()$ is function of memory effect, $\mathbf{D}$ is matrix of elasticity, $\tau$ is relaxation time.

Although it is not so common we can assume that as elastic strains as viscous-elastic strain are composed from thermal strain and moisture (swelling/ shrinkage) strain.

$\varepsilon_{\mathrm{c}}{ }^{\mathrm{el}}=\varepsilon^{\mathrm{el}}+\varepsilon_{\mathrm{w}}{ }^{\mathrm{el}}+\varepsilon_{\mathrm{T}}{ }^{\mathrm{el}}$

$\varepsilon_{\mathbf{c}}{ }^{\mathrm{vel}}=\varepsilon^{\mathrm{vel}}+\varepsilon_{\mathbf{w}}{ }^{\mathrm{vel}}+\varepsilon_{\mathbf{T}}{ }^{\mathrm{vel}}$,

$\varepsilon^{\mathrm{el}}$ is the whole elastic strain, $\varepsilon^{\mathrm{el}}$ is pure elastic strain, $\varepsilon^{\mathrm{el}}{ }_{\mathrm{w}}^{\mathrm{c}}$ is elastic strain due to moisture gradient, $\varepsilon^{\mathrm{el}}$ is elastic strain due to temperature gradient, $\varepsilon^{\mathrm{vel}}{ }_{\mathrm{c}}$ is the whole viscous-elastic strain, $\varepsilon^{\mathrm{vel}}$ is pure viscous-elastic strain, $\varepsilon^{\mathrm{vel}}$ is viscous-elastic strain due to moisture gradient and $\varepsilon^{\mathrm{vel}}{ }_{\mathrm{T}}$ is viscous-elastic strain due to temperature gradient.

Because separation of each part of viscous-elastic strain was not successfully realized yet, we can simplify this part by the following equivalence.

$\varepsilon_{\mathbf{c}}{ }^{\mathrm{vel}}=\varepsilon_{\mathbf{w}, \mathbf{T}}^{\mathrm{vel}}$

Withal value of this strain will be determined by appropriate coefficient that is related to moisture, temperature and time together. Mentioned components of strain can be defined by common way.

$$
\varepsilon_{\mathrm{w}}{ }^{\mathrm{el}} \equiv \mathrm{k}_{\mathrm{w}}{ }^{\mathrm{el}}\left(1-\frac{\mathrm{W}}{\mathrm{HL}}\right) \cdot\left(\alpha_{1}\left|\alpha_{2}\right| \alpha_{3}\left|\alpha_{4}\right| \alpha_{5} \mid \alpha_{6}\right)=\mathrm{k}_{\mathrm{w}}{ }^{\text {el }}\left(1-\frac{\mathrm{w}}{\mathrm{HL}}\right) \cdot \alpha, \mathrm{k}_{\mathrm{w}}{ }^{\mathrm{el}} \equiv\left\{\begin{array}{l}
\mathrm{k}_{\mathrm{w}}{ }^{\mathrm{el}}=1 \text { for } \mathrm{W} \leq \mathrm{HL} \\
\mathrm{k}_{\mathrm{w}}{ }^{\mathrm{el}}=0 \text { for } \mathrm{W}>\mathrm{HL}
\end{array}\right.
$$


$\varepsilon_{\mathrm{T}}^{\mathrm{el}} \equiv\left(\mathrm{T}-\mathrm{T}_{\mathrm{ext}}\right) \cdot\left(\beta_{1}\left|\beta_{2}\right| \beta_{3}\left|\beta_{4}\right| \beta_{5} \mid \beta_{6}\right)=\left(\mathrm{T}-\mathrm{T}_{\mathrm{ext}}\right) \cdot \beta$,

$\alpha$ is moisture expansion coefficient, $\beta$ is thermal expansion coefficient.

Integral form of Eq. (8) can be based on reduction of function $\Phi(t-\tau)$ to constant, then we write

$\sigma=\mathrm{D} \varepsilon_{\mathrm{c}}^{\mathrm{el}}+\lambda_{\mathrm{w}, \mathrm{T}} \frac{\partial \varepsilon_{\mathrm{w}, \mathrm{T}}^{\mathrm{vel}}}{\partial \mathrm{t}}$

$\lambda_{\mathbf{w}, \mathbf{T}}$ is vector of viscosity coefficients which depends on moisture and temperature.

\section{METHODS}

Mentioned relation between elastic coefficients and moisture/temperature agrees with common estimation of wood behavior (Bodig et al., 1989). Relation is usually negative in both parameters, but can be very complicated (according to anatomy structure). Dominant character of this relation with linear equation was described. For simplicity the equivalent change of strain due $w, T$ at each direction was proposed. This idea leads to independence of Poisson ratio in view of $w$, $T$ that is not in relation with nowadays experiments. Thus Young and Coulomb modules of elasticity are linear equation.

$\mathrm{E}_{\mathrm{w}_{\mathrm{i}}}=\mathrm{k}_{\mathrm{b}_{\mathrm{w}}}\left(\mathrm{w}-\mathrm{W}_{\mathrm{ext}}\right)+\mathrm{E}_{\mathrm{r}}$

$\mathrm{G}_{\mathrm{w}_{\mathrm{j}}}^{\mathrm{w}_{\mathrm{i}}}=\mathrm{k}_{\mathrm{b}_{\mathrm{j}}^{\mathrm{w}}}\left(\mathrm{w}-\mathrm{w}_{\mathrm{ext}}\right)+\mathrm{G}_{\mathrm{r}_{\mathrm{i}}}$,

For $i=1 \ldots 3, j=4 \ldots 6$.

Parameters were distinguished according to common bilinear behavior (at a point of hygroscopic limit (HL)).

$\mathrm{k}_{\mathrm{b}_{\mathrm{i}}^{\mathrm{w}}} \equiv\left\{\begin{array}{l}\mathrm{k}_{\mathrm{b}_{\mathrm{i}}^{\mathrm{w}}} \neq 0 \text { for } w \geq \mathrm{HL} \\ \mathrm{k}_{\mathrm{b}_{\mathrm{i}}^{\mathrm{w}}}=0 \text { for } w<\mathrm{HL}\end{array}\right.$

Derivation for temperature case is similar with appropriate advantage of the same bilinear relation and the same border point HL. Result elastic coefficients have adding appearance.

$E_{w_{i}}=E_{r_{i}}+k_{b_{i}^{w}}\left(w-w_{\text {ext }}\right)+k_{b_{i}^{T}}\left(T-T_{\text {ext }}\right)$

where: $k_{b w 0}$ and $k_{b T}$ are slopes of first part in bi-linear relation. Matrix of elastic coefficients can be separated into constant and dependent parts.

Let us declare matrix $\mathbf{D}_{\mathbf{x}}$.

$$
\mathbf{D}_{\mathbf{X}}=\left[\begin{array}{cccccc}
\frac{\left(\mu_{z, y} \mu_{y, z}-1\right) \mathrm{X}_{1}}{k_{\mathrm{D}}}-\frac{\left(\mu_{x, y}+\mu_{z, y} \mu_{x, y}\right) \mathrm{X}_{2}}{k_{\mathrm{D}}}-\frac{\left(\mu_{x, z}+\mu_{x, y} \mu_{y, z}\right) \mathrm{X}_{3}}{k_{\mathrm{D}}} & 0 & 0 & 0 \\
-\frac{\left(\mu_{y, x}+\mu_{z, x} \mu_{y, z}\right) \mathrm{X}_{1}}{k_{D}} & \frac{\left(\mu_{z, x} \mu_{x, z}-1\right) \mathrm{X}_{2}}{k_{D}} & -\frac{\left(\mu_{y, z}+\mu_{y, x} \mu_{x, z}\right) \mathrm{X}_{3}}{k_{D}} & 0 & 0 & 0 \\
-\frac{\left(\mu_{z, x}+\mu_{y, x} \mu_{z, y}\right) \mathrm{X}_{1}}{k_{D}}-\frac{\left(\mu_{z, y}+\mu_{z, x} \mu_{x, y}\right) \mathrm{X}_{2}}{k_{D}} & \frac{\left(\mu_{y, x} \mu_{x, y}-1\right) \mathrm{X}_{3}}{k_{D}} & 0 & 0 & 0 \\
0 & 0 & 0 & X_{4} & 0 & 0 \\
0 & 0 & 0 & 0 & X_{5} & 0 \\
0 & 0 & 0 & 0 & 0 & X_{6}
\end{array}\right]
$$

In this declaration we used $k_{\mathrm{D}}$ as constant with the following meaning $k_{D}=\mu_{z, y} \mu_{y, z}+\mu_{y, x} \mu_{x, y}+\mu_{y, x} \mu_{z, y} \mu_{x, z}+$ $\mu_{z, x} \mu_{x, y} \mu_{y, z}+\mu_{z, x} \mu_{x, z}-1$ and vector $\mathbf{X}=\left(X_{1}, X_{2}, X_{3}, X_{4}\right.$, $\left.X_{5}, X_{6}\right)$ for simple substitution during separation. Now we can define matrix of elasticity $\mathbf{D}$.

$\mathbf{D}=\left.\mathbf{D}_{\mathbf{X}}\right|_{\mathbf{X}=\mathbf{E} \mathbf{G}}+\left.\left(w-w_{e x t}\right) \cdot \mathbf{D}_{\mathbf{X}}\right|_{\mathbf{X}=\mathbf{K}_{\mathbf{b}} \mathbf{w}}+\left.\left(T-T_{e x t}\right) \cdot \mathbf{D}_{\mathbf{X}}\right|_{\mathbf{X}=\mathbf{K}_{\mathbf{b}} \mathbf{T}}$

Withal $\mathbf{E G}=\mathbf{E}_{\mathbf{r}} \circ \mathbf{G}_{\mathrm{r}} \equiv\left(\mathrm{E}_{\mathrm{x}}, \mathrm{E}_{\mathrm{y}}, \mathrm{E}_{\mathrm{z}}, \mathrm{G}_{\mathrm{xy}}, \mathrm{G}_{\mathrm{yz}}, \mathrm{G}_{\mathrm{xz}}\right)$ $\mathbf{K}_{b^{w}} \equiv\left(k_{b_{1}^{w}}, k_{b_{2}^{w}}, k_{b_{3}^{w}}, k_{b_{4}^{w}}, k_{b_{5}^{w}}, k_{b_{6}^{w}}\right)$ respective

$$
\sigma=\left(\mathbf{D}_{\mathbf{E G}}+\left(w-w_{e x t}\right) \cdot \mathbf{D}_{\mathbf{K}_{\mathbf{b}} \mathbf{w}}+\left(T-T_{e x t}\right) \cdot \mathbf{D}_{\mathbf{K}_{\mathbf{b}} \mathbf{T}}\right) \cdot\left(\varepsilon^{\mathrm{el}}+k_{w}^{e l}\left(1 \frac{w}{H L}\right) \cdot \alpha+\left(T-T_{e x t}\right) \cdot \beta\right)+\lambda_{\mathbf{w}, \mathbf{T}} \frac{\partial \varepsilon_{\mathbf{w}, \mathbf{T}}^{\text {vel }}}{\partial t}
$$

Eq. (18) is combined with stress equilibrium conditions including transient effects:

$\rho \frac{\partial^{2} \mathbf{u}}{\partial t^{2}}-\frac{\partial \sigma_{i j}}{\partial x_{j}}=F_{i}$ $\mathbf{u}$ is vector of displacements $\mathbf{u} \equiv(u, v, w), F_{i}$ are components of volume forces

Withal strains are declared by common way. 
$\varepsilon^{\mathrm{el}} \equiv\left(\frac{\partial \mathrm{u}}{\partial \mathrm{x}}\left|\frac{\partial \mathrm{v}}{\partial \mathrm{y}}\right| \frac{\partial \mathrm{w}}{\partial \mathrm{z}}\left|\frac{1}{2}\left(\frac{\partial \mathrm{u}}{\partial \mathrm{y}}+\frac{\partial \mathrm{v}}{\partial \mathrm{x}}\right)\right| \frac{1}{2}\left(\frac{\partial \mathrm{v}}{\partial \mathrm{z}}+\frac{\partial \mathrm{w}}{\partial \mathrm{y}}\right) \mid \frac{1}{2}\left(\frac{\partial \mathrm{w}}{\partial \mathrm{x}}+\frac{\partial \mathrm{u}}{\partial \mathrm{z}}\right)\right)$

$\varepsilon_{\mathrm{w}, \mathrm{T}}^{\text {vel }} \equiv\left(\frac{\partial \mathrm{u}_{1}}{\partial \mathrm{x}}\left|\frac{\partial \mathrm{v}_{1}}{\partial \mathrm{y}}\right| \frac{\partial \mathrm{w}_{1}}{\partial \mathrm{z}}\left|\frac{1}{2}\left(\frac{\partial \mathrm{u}_{1}}{\partial \mathrm{y}}+\frac{\partial \mathrm{v}_{1}}{\partial \mathrm{x}}\right)\right| \frac{1}{2}\left(\frac{\partial \mathrm{v}_{1}}{\partial \mathrm{z}}+\frac{\partial \mathrm{w}_{1}}{\partial \mathrm{y}}\right) \mid \frac{1}{2}\left(\frac{\partial \mathrm{w}_{1}}{\partial \mathrm{x}}+\frac{\partial \mathrm{u}_{1}}{\partial \mathrm{z}}\right)\right)$

$\mathbf{u}^{\mathrm{vel}} \equiv\left(\mathrm{u}^{\mathrm{vel}}, \mathrm{v}^{\mathrm{vel}}, \mathrm{w}^{\mathrm{vel}}\right)$

$\mathbf{u}^{\mathrm{vel}}$ is viscous-elastic supply of displacement.
The final relationship for stress-strain components according to unknown variable displacement $\mathbf{u}$ respective $\mathbf{u}^{\text {vel }}$ can be formed in this grouped form.

$\rho \frac{\partial^{2} \mathbf{u}}{\partial \mathrm{t}^{2}}-\left(\nabla \mathbf{c}_{\mathbf{E G}}+\left(\mathrm{w}-\mathrm{W}_{\mathrm{ext}}\right) \nabla \mathbf{c}_{\mathbf{K}_{\mathrm{b}} \mathbf{w}}+\left(\mathrm{T}-\mathrm{T}_{\mathrm{ext}}\right) \nabla \mathbf{c}_{\mathbf{K}_{\mathbf{b}}}\right) \nabla \mathbf{u}-\nabla \mathbf{c}_{\lambda_{\mathbf{w}, \mathbf{T}}} \nabla \frac{\partial \mathbf{u}_{\mathbf{v e l}}}{\partial \mathrm{t}}+\mathbf{C}_{\mathbf{w}} \cdot \mathrm{W}+\mathbf{C}_{\mathbf{w}^{2}} \cdot \mathrm{w}^{2}+\mathbf{C}_{\mathbf{T}} \cdot \mathrm{T}+\mathbf{C}_{\mathbf{T}^{2}} \cdot \mathrm{T}^{2}+\mathbf{C}_{\mathbf{w T}} \cdot \mathrm{wT}+\mathbf{C}=\mathbf{F}$

Definition of $\mathrm{C}$ coefficients can be revealed by simple rearranging.

$$
\begin{aligned}
& \mathbf{C}_{\mathbf{w}}=\left(\frac{\mathrm{k}_{\mathrm{w}}^{\mathrm{el}}}{\mathrm{HL}}\left(\mathbf{D}_{\mathrm{EG}}+\mathrm{T}_{\mathrm{ext}} \mathbf{D}_{\mathbf{K}_{\mathrm{b}} \mathrm{T}}\right) \cdot \alpha+\mathbf{D}_{\mathbf{K}_{\mathrm{b}} \mathrm{w}}\left(\mathrm{k}_{\mathrm{w}}^{\mathrm{el}}\left(1-\frac{\mathrm{w}_{\mathrm{ext}}}{\mathrm{HL}}\right) \cdot \alpha-\mathrm{T}_{\mathrm{ext}} \beta\right)\right) ; \mathbf{C}_{\mathbf{w}^{2}}=\frac{\mathrm{k}_{\mathrm{w}}^{\mathrm{el}}}{\mathrm{HL}} \Delta \mathbf{D}_{\mathrm{K}_{\mathrm{b}} \mathrm{w}} \alpha \\
& \mathbf{C}_{\mathbf{T}}=\left(\left(\mathbf{D}_{\mathbf{E G}}-\mathrm{W}_{\text {ext }} \mathbf{D}_{\mathbf{K}_{\mathrm{b}}{ }_{\mathrm{w}}}\right) \cdot \beta+\mathbf{D}_{\mathbf{K}_{\mathbf{b}} \mathbf{T}}\left(\mathrm{k}_{\mathrm{w}}^{\mathrm{el}} \alpha-2 \mathrm{~T}_{\mathrm{ext}} \beta\right)\right) ; \mathbf{C}_{\mathbf{T}^{2}}=\mathbf{D}_{\mathbf{K}_{\mathbf{b}} \mathbf{T}} \beta
\end{aligned}
$$

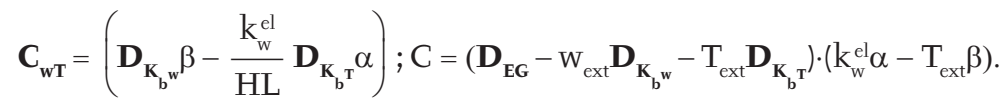

Matrixes of diffusion constants (c) can be defined by similar way as matrix of elastic constants (D). Let us define matrix $\mathbf{c}_{\mathbf{x}}$.

$\mathbf{c}_{\mathbf{X}}=\left[\begin{array}{ccccccccc}D_{X 11} & 0 & 0 & 0 & D_{X 12} & 0 & 0 & 0 & D_{X 13} \\ 0 & \frac{1}{2} D_{X 44} & 0 & \frac{1}{2} D_{X 44} & 0 & 0 & 0 & 0 & 0 \\ 0 & 0 & \frac{1}{2} D_{X 66} & 0 & 0 & 0 & \frac{1}{2} D_{X 66} & 0 & 0 \\ 0 & \frac{1}{2} D_{X 44} & 0 & \frac{1}{2} D_{X 44} & 0 & 0 & 0 & 0 & 0 \\ D_{X 21} & 0 & 0 & 0 & D_{X 22} & 0 & 0 & 0 & D_{X 23} \\ 0 & 0 & 0 & 0 & 0 & \frac{1}{2} D_{X 55} & 0 & \frac{1}{2} D_{X 55} & 0 \\ 0 & 0 & \frac{1}{2} D_{X 66} & 0 & 0 & 0 & \frac{1}{2} D_{X 66} & 0 & 0 \\ 0 & 0 & 0 & 0 & 0 & \frac{1}{2} D_{X 55} & 0 & \frac{1}{2} D_{X 55} & 0 \\ D_{X 31} & 0 & 0 & 0 & D_{X 32} & 0 & 0 & 0 & D_{X 33}\end{array}\right]$

Individual matrixes can be declared by substitution of $\mathrm{X}$.

$$
\begin{aligned}
& \mathbf{c}_{\mathbf{E G}}=\left.\mathbf{c}_{\mathbf{X}}\right|_{\mathbf{X}=\mathbf{E G}}, \mathbf{c}_{\mathbf{K}_{\mathbf{b}} \mathbf{w}}=\left.\mathbf{c}_{\mathbf{X}}\right|_{\mathbf{X}=\mathbf{K}_{\mathbf{b}} \mathbf{w}}, \mathbf{c}_{\mathbf{K}_{\mathbf{b}} T}=\left.\mathbf{c}_{\mathbf{X}}\right|_{\mathbf{X}=\mathbf{K}_{\mathbf{b}} T} \\
& \mathbf{c}_{\lambda_{\mathbf{w}, \mathbf{T}}}=\left[\begin{array}{ccccccccc}
\lambda_{1} & 0 & 0 & 0 & \frac{1}{4} \lambda_{4} & 0 & 0 & 0 & \frac{1}{4} \lambda_{6} \\
0 & \frac{1}{2} \lambda_{4} & 0 & \frac{1}{4} \lambda_{4} & 0 & 0 & 0 & 0 & 0 \\
0 & 0 & \frac{1}{2} \lambda_{6} & 0 & 0 & 0 & \frac{1}{4} \lambda_{6} & 0 & 0 \\
0 & \frac{1}{4} \lambda_{4} & 0 & \frac{1}{2} \lambda_{4} & 0 & 0 & 0 & 0 & 0 \\
\frac{1}{4} \lambda_{4} & 0 & 0 & 0 & \lambda_{2} & 0 & 0 & 0 & \frac{1}{4} \lambda_{5} \\
0 & 0 & 0 & 0 & 0 & \frac{1}{2} \lambda_{5} & 0 & \frac{1}{4} \lambda_{5} & 0 \\
0 & 0 & \frac{1}{4} \lambda_{6} & 0 & 0 & 0 & \frac{1}{2} \lambda_{6} & 0 & 0 \\
0 & 0 & 0 & 0 & 0 & \frac{1}{4} \lambda_{5} & 0 & \frac{1}{2} \lambda_{5} & 0 \\
\frac{1}{4} \lambda_{6} & 0 & 0 & 0 & \frac{1}{4} \lambda_{5} & 0 & 0 & 0 & \lambda_{3}
\end{array}\right]
\end{aligned}
$$


Described model is valid for diffusive transport of moisture and temperature. It is not appropriate (due physical nature of phenomenon) for free water movement. This transport is allocated into intercellular spaces and cell lumen. Description of this process can be done with Navier-Stokes equation

$\frac{\partial \mathrm{v}}{\partial \mathrm{t}}+(\nabla \times v) \times v+\frac{1}{2} \nabla v^{2}=-\frac{\nabla \mathrm{p}^{\mathrm{fl}}}{\rho}-\nabla \mathrm{U}+\frac{\eta}{\rho} \nabla^{2} v$

where: $\nabla \mathrm{U}$ is potential, $v$ is velocity of fluid.

Gradient of hydrostatic pressure was evaluated in non-turbulent flux

$\rho\left(\frac{\eta}{\rho} \nabla^{2} v-\nabla \frac{\mathbf{F}}{\partial \mathrm{x} \partial \mathrm{y} \partial \mathrm{z}}-\frac{1}{2} \nabla v^{2}-\frac{\partial v}{\partial \mathrm{t}}\right)=\nabla p^{f l}$

Eq. (24) makes sense for regions of fluids (water, steam) and can be used for multiple species transport. Coupling with the solid phase is done by these relations.

$\mathbf{u}^{\mathrm{fl}}=\mathbf{u}+\mathbf{u}^{\mathrm{vel}}$ on $\Gamma$

$\mathrm{p}^{\mathrm{fl}}=\mathrm{p}$,

$\mathbf{u}^{\mathrm{fl}}$ is vector of displacements, which has to be equal to sum of elastic $(\mathbf{u})$ and viscous-elastic $\left(\mathbf{u}^{\text {vel }}\right)$ displacements on interface $\Gamma$ of fluid and solid, $p^{f l}$ is hydrostatic pressure.

System of equations (2) and (7) together with Eq. (21) and Eq. (24) are sufficient for solution of very general problem of wood drying problem. Most of material properties keep orthotropic character and coupled dependency on moisture, temperature and hydrostatic pressure. This project holds notation natural for common multiphysics solvers such as FEMLAB/COMSOL and can be simply implemented. The whole system is relative simple, but is it really solvable and useable for such complicated structure as wood? There is not single-valued answer. From mathematical point of view there are a lot of techniques (mainly variation formulation of problem and solution on base of finite element method) which allows solving the problem. On the contrary, there is the most difficult problem with definition of material characteristics. It is not only question how to obtain properties and how to realize experiments to derivation of homogenized properties. Important problem is high variability of such obtained values. Frequently, the probabilistic analysis based on FE simulation of such values leads to unreasonable results when researcher tries exhausting the whole range of statistical distribution of each parameter. Promising way of this problem can be modeling "ab initio". This type of simulation constructs models by bottom-top hierarchy. It provides very important advantage in much simpler material models. Complexity of solved problem is made neither by definition of complicated geometry nor by material. Constitutional relationships of physical model may be the same or simpler again. A lot of projects were done on this topic (also in our team (JAVOŘíK, 2000; KoŇAs, 2003a,b)).

\section{RESULTS AND DISCUSSION}

In our investigation we have focused on wood with regular structure which consists predominately of tracheid cells (Fig. 2). The symbolic representative is spruce (Picea spp.). The least structural member was tracheid. This type of wood forms polar structure with regular parts of parallel tracheid row. Row consists of successive tracheid cells in radial direction. Each row has initial necking which spreads until the maximal cross width of tracheid is reached for. Except them, the row can be decomposed into periodic parts of late and early wood. Periodicity is not ideal in this term because input functions of morphology parameters (according to obvious nature cases) have general multinomial character without necessary condition of periodicity. The row doesn't keep

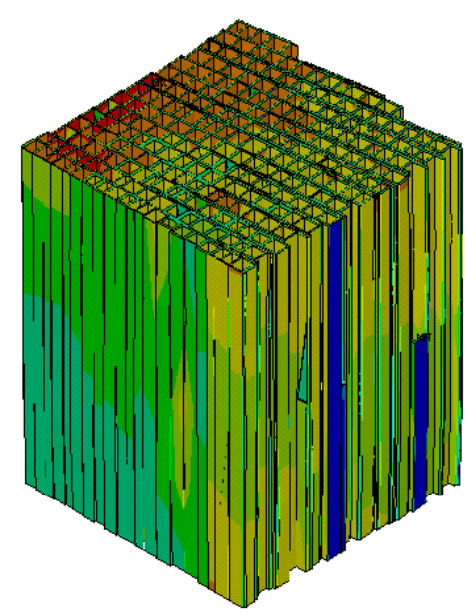

1: Probabilistic FE model of wood structure on micro-scopic scale level

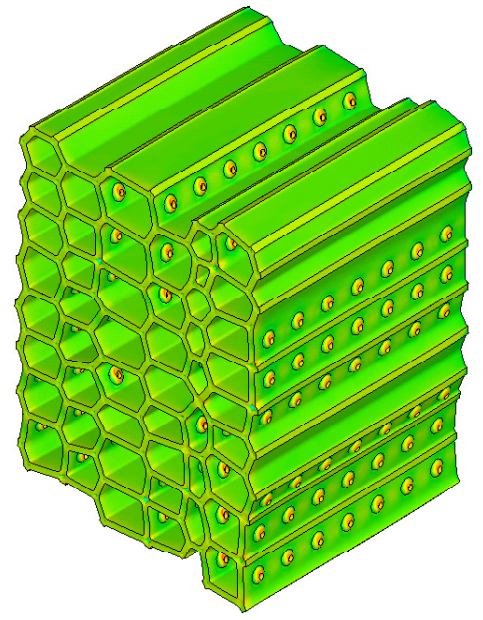

2: Structure of wood includ-ing border pits (author J. Javorík)

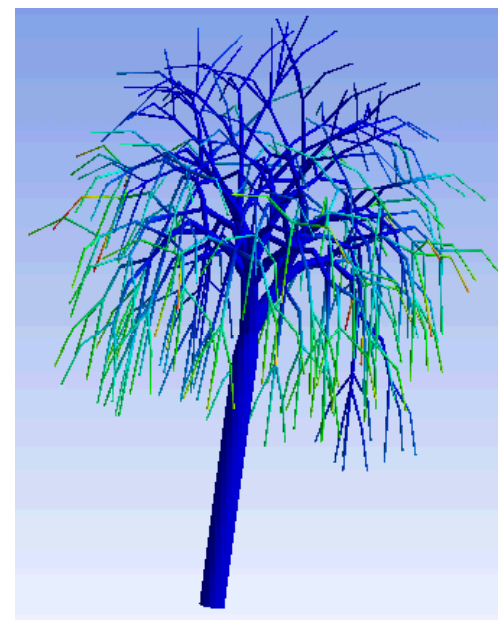

3: L-system based FE model of tree structure. Von Mises stress in tree due to gravity forces. 
the constant tracheid cross width in height sections, but gains the value of relevant morphology scaled function. In addition, this way formed plane of tracheids is not simply extruded, but random (controlled) shift of next cell according to previous position was included. Tracheid planes are than assembled together. The way of material contact is derived from geometry condition of full continuity of modeled space. Algorithm of row adjustment with continuity condition was described in (KoŇAs, 2001b). Procedure was named "nesting" according to iterative process of nesting of new tracheid planes between two or three existing (previous) planes. The procedure forms a fractal structure, which satisfy conditions of row similarity and shared cohesion within each component. Derived structure thus answers geometry condition only. The named_morphology parameters were width and length of tracheid and thickness within cell wall. These parameters are common in morphology studies and enough for structure assembling. The study which we have released from (GANDELOVÁ, 1989) occupies these parameters on macro scale (among growth rings), sub-macro scale (within growth-ring with wood type resolution (early and late)) and micro scale within one tracheid. From measured data we were able to reconstruct values of distribution parameters on each scale level for all variables. Linkage between scales was realized by so-called ,transmition' functions defined in (KoŇAs, 200la). Functions return the mean value and standard deviation of morphology parameters in radius position from the stem centre and height position within the stem. Random effect from statis- tic distributions is constrained with several proved conditions of occurrence possibility. There is conditioned occurrence of parameter extremes and ratios between them (width/length and thickness/ length). Intercellular spaces (ICS) in case of spruce are obviously filled by lignin matrix (we use the general term ICS for space description between tracheids). ICS are usually conditioned by maximal and/ or minimal possible values of free distance between structural members.

Results from mentioned projects provide interesting results. Nevertheless the problem of small amount of input parameters according to required accuracy sufficient for reasonable modeling turned from problem "how to obtain material properties" to problem "how to describe appropriate geometry". Author hopes that solution of this partial problem can be techniques of L-systems, DOL-systems and other languages that allow to model biological structure by evolutionary way. By these tools we are able to model as microscopic as macroscopic structures on really large scales. Nowadays it is possible to convert L-system based structures to FE model. Nevertheless, current program code is not able to combine FE model transformation during evolution phase of structure. Our future work will be focused on implementation of converter into the native L-language. Results of this task will allow not only simulation of dynamical effects of biology structures growing on arbitrary scale level, but also appropriate homogenization for selected level including effects of surrounding environment.

\section{SUMMARY}

The coefficient form of general PDE notation for coupled physical task of microwave drying of wood with free water and moisture movement together with moisture/temperature dependency of material model and base phenomenological description of such physical fields on wood structure was found. Description is based on well known but separated relationships which are usually solved separately regardless of coupling effects. The paper presents natural and relative simple way for evaluation of individual coefficient tensors/matrix forms which solve fully coupled model. Suggested very complex model is referenced to results derived on models of wood structure on very low (anatomical) and very high (on scale of tree) scale level. Discussion about future of L-systems in FE modeling of wood was realized.

\section{SOUHRN}

Obecný model dřeva v typických vázaných úlohách, Část I. - Fenomenologický přistup

Byla sestavena koeficientová podoba obecného zápisu jednoduchých parciálních diferenciálních rovnic sdružené fyzikální úlohy mikrovlného sušení dřeva včetně pohybu vlhkosti i vody volné a společně s vlhkostní/teplotní závislostí materiálového modelu a základním fenomenologickým popisem těchto fyzikálních polí ve struktuře dřeva. Popis je založen na všeobecně známých, avšak samostatných vztazích, které jsou obvykle řešeny odděleně bez ohledu na vázané jevy. Tato práce představuje př̀irozený a relativně snadný způsob pro odvození jednotlivých koeficientových tensorových/maticových forem, které řeší úplný sdružený fyzikální problém. Navrhovaný velmi komplexní model je vztažen $\mathrm{k}$ dosaženým výsledkům modelů struktury dřeva na velmi malém (anatomickém) i značně velkém (na úrovni stromu) měřítku.

MKP, vázané fyzikální úlohy, sušení dřeva 


\section{ACKNOWLEDGEMENT}

The work is supported by project GAČR GP106/06/P363 (P526563605) - Homogenization of material properties of wood for tasks from mechanics and thermodynamics.

\section{REFERENCES}

KRIEGSMANN, G. A., 1997: Hot spot formation in microwave heated ceramic fibres. IMA Journal of Applied Mathematics, 59 (2): pp. 123-148

BODIG, J., JAYNE, B. A., 1982: Mechanics of wood and wood composites, New York: Van Nostrand Reinhold: pp. 736

GANDELOVÁ, L., 1989: Charakteristika tracheidy u smrku (Picea Abies /L./KARST.), Perspectivy rozvoje lesního hospodárštví - článek z mezinárodní vědecké konference Vysoké školy zemědělské $\mathrm{v}$ Brně, 32 stran

JAVOŘİK, J., 2000: Modelování mechanického chování dřeva metodou konečných prvků, Programy a algoritmy numerické matematiky 10. Praha, AV ČR, 75 stran

KOŇAS, P., 2001: Parametric FE model of wood, in proceedings of 9. ANSYS Users' meeting, Třešt', pp. 128

KOŇAS, P., 2001: General concept of finite element model based on wood anatomy structure I, proceedings of MendelNET 01, MZLU Brno, pp. 19-22

KOŇAS, P., 2003: General koncept of Finite Element (FE) model based on anatomy structure (part V Probabilistic FEM model of wood), ACTA Universitatis agriculturae et silviculturae Mendelianae Brunensis, LI, number 1, Brno pp. 69-76

KOŇAS, P., 2003: Hraje Bůh dřevěnými kostkami?, VESMÍR 82, červen, pp. 317-321 
